\title{
Lightweight Cellular Hollow Concrete Blocks Containing Volcanic Tuff Powder, Expanded Clay and Diatomite for Non-Load Bearing Walls
}

\author{
Lütfullah GÜNDÜZ1 \\ Şevket Onur KALKAN ${ }^{2}$
}

\begin{abstract}
Lightweight cellular hollow concrete (LCHC) block is a type of masonry unit manufactured by precast technique. LCHC blocks are produced by the mixing of Portland cement, volcanic tuff, expanded clay and diatomite for building applications. LCHC blocks are lightweight, and the frequent cellular holes provide excellent thermal and acoustic performance, fire resistance and resistance to harsh environmental conditions. In this research work, LCHC blocks with 28 different mix proportions were cast into a mould with vibro-compacting, demoulded immediately and transferred to a storage area for curing up to 120 days in standard air condition at room temperature. The blocks were designed with 21 cellular spaces of 10 $\mathrm{mm}$ width. For each mixture, twenty four block specimens were prepared and tested in the air dry condition for compressive strength and water absorption in accordance with BS 1881: Part 116. This paper initially examines how volcanic tuff powder affects the characteristics of lightweight concrete masonry mixtures and investigates the use of quaternary blends containing volcanic tuff, expanded clay, diatomite and Portland cement to produce LCHC blocks for partitioning walls.
\end{abstract}

Keywords: Lightweight concrete, volcanic tuff, expanded clay, diatomite, masonry block.

\section{INTRODUCTION}

The production of lightweight concrete masonry units transformed from a hand cast process to a highly automated one during the past 100 years. Single moulds compacted by hand gave way to ganged moulds that travel on assembly lines in high-tech manufacturing facilities. These changes have also led to excellent quality control and uniformity of units [1]. Concrete masonry units are manufactured with very dry, stiff concrete mixtures. The "no-slump" or

\footnotetext{
Note: July 17, 2019.

- Discussions on this paper will be accepted by January 31, 2021.

- https://dx.doi.org/10.18400/tekderg.426034

1 İzmir Kâtip Çelebi University, Department of Civil Engineering, İzmir, Turkey lutfullah.gunduz@ikc.edu.tr - https://orcid.org/0000-0003-2487-467X

2 İzmir Kâtip Çelebi University, Department of Civil Engineering, İzmir, Turkey sevketonur.kalkan@ikc.edu.tr - https://orcid.org/0000-0003-0250-8134
}

- This paper has been received on May 22, 2018 and accepted for publication by the Editorial Board on 
"low-slump" material is placed into moulds, vibrated and compacted, and demoulded quickly. The demoulded units are stiff enough to hold their shape as they enter the curing chamber. Afterwards, they are palletized and readied for shipping [1]. They could be manufactured, adding to local economies and meeting sustainability criteria.

Lightweight concrete masonry blocks are primarily used as building materials in the construction of walls. Concrete blocks are one of several precast concrete products used in construction. Most concrete blocks have one or more hollow cavities, and their sides may be cast smooth or with a design. In use, concrete blocks are stacked one at a time and jointed with fresh cementitious mortar to form the desired length and height of the wall.

The concrete mixtures commonly used to make normal weight concrete masonry blocks is a mixture of Portland cement, water, sand, and gravel. This produces a light grey block with a fine surface texture and a sufficiently high compressive strength. This type of blocks is generally used for building load-bearing walls and partitions. Typical mass of this type of concrete block ranges from $16 \mathrm{~kg}$ to $27 \mathrm{~kg}$. In general, the concrete mixture used for blocks has a higher percentage of sand and a lower percentage of gravel and water than the concrete mixtures used for general construction purposes. If lightweight aggregates are used instead of normal weight sand and gravel, the resulting block is commonly called a lightweight concrete masonry block. This produces more porous and lighter blocks with a medium-tocoarse surface texture, good strength, good sound-deadening properties, and a higher thermal insulating value than a normal weight concrete block. LCHC blocks made of different lightweight aggregates, cement and water are used in construction of non-load bearing infill walls and slabs. Lightweight blocks can be manufactured with densities ranging from 400 $\mathrm{kg} / \mathrm{m}^{3}$ to $1100 \mathrm{~kg} / \mathrm{m}^{3}$ effecting an average reduction in dead load of $40 \%$ to $50 \%$ as compared to those of buildings with conventional concrete walls [2, 3, 4]. A typical lightweight concrete masonry block has a mass of $5 \mathrm{~kg}$ to $14 \mathrm{~kg}$ depending on the mineralogical composition, the particle shape and grading of the aggregate.

In general, units with lower density will not only reduce the dead load of a structure, but will also have better thermal insulating properties and provide increased mason productivity during installation. These factors can result in significant overall cost savings. LCHC blocks allow increased productivity in production, delivery, handling, and installation. The fire resistance rating of a lightweight concrete masonry unit depends on its equivalent thickness and the types of aggregate used in its manufacture.

Aggregate size and gradation are the most important factors when selecting aggregate in lightweight masonry mixtures. Aggregate particle sizes range from coarse-sized granulates to fine-sized powder [6]. As a general rule, the largest aggregate should be no greater in size than one-third the depth of the slab, or one-fifth the smallest dimension of the form. Since the mortar samples to be produced are poured into the moulds and the mould openings are $22 \mathrm{~mm}$ wide, maximum fine aggregate grain size is selected as $1 \mathrm{~mm}$. Well-graded aggregates may be used to reduce the amount of cement paste required and thus, decrease the amount of shrinkage that could occur.

The volumetric majority of the low slump masonry concrete consists of lightweight aggregates. It is a basic objective that the cement paste coats and binds together the aggregate particles. The composition, shape, porosity, size and type of the aggregate all have significant effect on the workability, durability, strength, unit weight, and shrinkage of the lightweight 
concrete. Aggregate can also influence the texture and appearance of the cast surface, which is an especially important consideration in concrete masonry block making mixes.

Lightweight aggregates have maximum dry loose bulk densities of about $880 \mathrm{~kg} / \mathrm{m}^{3}$ for the coarse fractions and $1040 \mathrm{~kg} / \mathrm{m}^{3}$ for all-in aggregates [7]. Lightweight aggregates are also classified as natural and artificial depending on the final source they are obtained. The main natural lightweight aggregates are diatomite, pumice, scoria, volcanic slug, and volcanic tuff. Except for diatomite, all are volcanic in origin. Pumice and scoria are more widely used for hollow and solid concrete block production in Turkey [8,9]. However, using the expanded clay in masonry block productions is a relatively new experience in Turkey.

Due to the low aggregate strength characterizations, diatomite aggregates alone are not generally preferred for use in production of lightweight masonry blocks. However, diatomite aggregates could be used with strength enhancer materials to ensure a sufficient strength requirement for lightweight masonry blocks. Volcanic tuff powders are one of the wellknown strength enhancer natural materials due to their pozzolanic properties. Also expanded clay aggregates are used in concrete masonry blocks to improve the strength.

Although many lightweight aggregates are suitable for use in lightweight masonry blocks, inclusion of volcanic tuff powder as a strength enhancer material in the mixture does not appear as a widespread practice in literature. In this respect, a research work was carried out to optimize the lightweight masonry blocks according to the related standards by using volcanic tuff as a strength enhancer material. This research work presents the technical results of a comprehensive experimental study on optimizing the lightweight masonry blocks for non-load bearing walls.

\section{EXPERIMENTAL STUDY}

\subsection{Experimental Scope}

The experimental work was carried out in order to determine the suitability for use of quaternary blends containing volcanic tuff, expanded clay aggregate, diatomite and cement to produce LCHC blocks for non-load bearing walls and partitions. Initially, the aim of the work was to evaluate the use of volcanic tuff and expanded clay aggregate as strength enhancers to improve the lightweight concrete properties. A series of comprehensive tests were carried out to analyse the effects of volcanic tuff and expanded clay aggregate on the constituent material composition, unit weight, compressive strength and water absorption properties. The effects of use of fine and coarse diatomite aggregates in production of lightweight masonry blocks were also determined.

\subsection{Materials Used in the Research}

The lightweight concrete masonry hollow blocks with dimensions of $185 \mathrm{~mm}$ height, 390 $\mathrm{mm}$ length and $190 \mathrm{~mm}$ width, in general use in Turkey, were used throughout the experimental work. The web and shell thicknesses of the hollow lightweight units were 22 $\mathrm{mm}$. In total, each block contained 21 cellular spaces of $10 \mathrm{~mm}$ width. The model of masonry unit is shown in Fig. 1 
Portland cement (CEM I 42.5) which is comparable to ASTM Type $1\left(42.5 \mathrm{~N} / \mathrm{mm}^{2}\right)$ was used throughout this research. The chemical composition and physical properties of the cement used in this research are given in Tables 1 and 2.

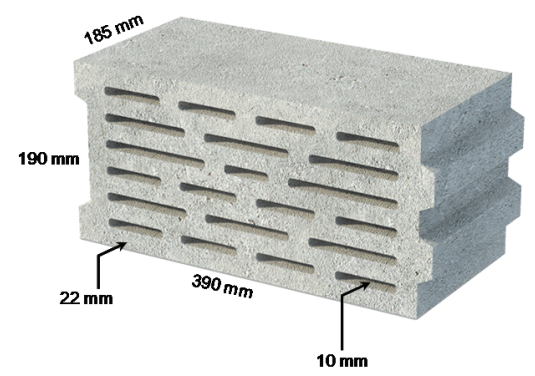

Figure 1 - The model of masonry unit

Table 1 - Chemical compositions of CEM I, VTP, ECA, FDA and CDA (mass\%)

\begin{tabular}{lrrrr}
\hline Major element & CEM I & VTP & ECA & FDA and CDA \\
\hline $\mathrm{SiO}_{2}$ & 20.92 & 61.44 & 51.60 & 68.74 \\
$\mathrm{Al}_{2} \mathrm{O}_{3}$ & 5.18 & 12.48 & 14.80 & 8.94 \\
$\mathrm{Fe}_{2} \mathrm{O}_{3}$ & 3.87 & 4.34 & 11.75 & 14.23 \\
$\mathrm{CaO}$ & 62.44 & 5.10 & 8.40 & 0.69 \\
$\mathrm{Na} \mathrm{O}_{2} \mathrm{O}$ & 0.19 & 1.65 & 1.13 & 0.34 \\
$\mathrm{~K}_{2} \mathrm{O}$ & 0.78 & 1.38 & 1.24 & 1.58 \\
$\mathrm{MgO}$ & 2.45 & 6.40 & 5.60 & 0.61 \\
$\mathrm{LOI}$ & 1.51 & 1.80 & 3.20 & 7.80 \\
\hline $\mathrm{CEM} \mathrm{I}$ & $:$ Portland cement TS EN 197-1 & & & \\
$\mathrm{VTP}$ & : volcanic tuff powder & & & \\
ECA & $:$ expanded clay aggregate & & & \\
FDA & $:$ fine diatomite aggregate & & & \\
CDA & : coarse diatomite aggregate & & &
\end{tabular}

Table 2 - Mechanical and physical properties of CEM I

\begin{tabular}{ll}
\hline Specific gravity & 3.10 \\
Blaine specific surface $\left(\mathrm{m}^{2} / \mathrm{kg}\right)$ & 324.5 \\
Initial setting time $(\mathrm{min})$ & 250 \\
Final setting time $(\mathrm{min})$ & 360 \\
Volume expansion $(\mathrm{mm} / \mathrm{m})$ & 0.87 \\
Compressive strength $(\mathrm{MPa})$ & \\
2 days & 14.7 \\
7 days & 26.9 \\
14 days & 34.7 \\
28 days & 43.0 \\
\hline
\end{tabular}


As strength enhancer materials, two different aggregate types namely volcanic tuff and expanded clay aggregate were used. Volcanic tuff aggregate used in this experimental study was obtained from the location of ignimbrite Mining Quarry in Aksaray Region, Central Anatolia. Volcanic tuff obtained from the quarry was only crushed by a primer crusher and then screened to obtain the $0 / 1 \mathrm{~mm}$ filler fraction (VTP) The tuff was found to be composed of rounded particles when optically analysed using a microscope. Because, it was observed in the microscope analysis that rounded shape tuff particles have an ability to do a well filling affect in the matrix structure. Optical microscopic analysis showed that the tuff contained well-rounded particles which enhance workability, filling effect, and, thus strength.

Natural pozzolans constitute a part of the lightweight aggregate group that could increase the strength and durability of concrete in the production of block making mixtures. Tuff aggregate in powder form is one of the well-known pozzolans used in concrete applications.

The expanded clay aggregates were obtained from the clay mining quarries at Kalecik Region in Ankara, Central Turkey. The clay aggregates obtained from the quarry were first crushed and then grounded into a powder form. Clay pellets were made with potable water without using any admixture in laboratory conditions. Then all pellets were expanded in a kiln at $1050{ }^{\circ} \mathrm{C}$ to produce expanded clay aggregate (ECA). After expanding, they were screened into 4/8 mm size fractions. Diatomite aggregates were obtained from the diatomite mining quarries at Kazan Region in Ankara, Central Turkey. Diatomite aggregates were used in their natural state (as mined), without any calcination. Similar to VTP, the diatomite aggregates were also first crushed by a primer crusher, and then screened into $0 / 4 \mathrm{~mm}$ and $4 / 8 \mathrm{~mm}$ size fractions as fine diatomite aggregate (FDA) and coarse diatomite aggregate (CDA), respectively. The chemical compositions of these materials are given in Table 1. Dry bulk density, water absorption and compressive strength values of VTP, ECA, FDA and CDA, given in Table 3, were determined according to the BS 812:P2 [10], BS 812:P110 [11], ASTM C127 [12] and ASTM C128 [13].

Table 3 - Physical properties of VTP, ECA, FDA and CDA

\begin{tabular}{lccc}
\hline Material & Specific Gravity & $\begin{array}{c}\text { Dry bulk density } \\
\left(\mathrm{kg} / \mathrm{m}^{3}\right)\end{array}$ & $\begin{array}{c}\text { Water } \\
\text { Absorption } \\
(\mathrm{wt} \%)\end{array}$ \\
\hline VTP & 2.21 & 1240 & 33.8 \\
ECA & 2.48 & 976 & 35.7 \\
FDA & 2.33 & 413 & 60.8 \\
CDA & 2.33 & 326 & 71.4 \\
\hline
\end{tabular}

Tuff, a pyroclastic rock of consolidated volcanic ash origin, is sometimes called tufa or ashstone, particularly when used as construction material, although tufa also refers to a quite different rock. Rock that contains greater than $50 \%$ tuff is considered tuffaceous $[14,15,16$, 17]. Its highly vesicular but compacted and consolidated structure gives it a higher strength.

The volcanic tuff aggregate in its natural form has been used to increase the compressive strength and decrease the density of masonry blocks. Initial and final setting times increase when the quantity of tuff increases, resulting in a slower compressive strength development. 
The advantages of tuff include its highly porous structure, high surface area, and low density. It is available in different types, sizes, and colours, and can reduce the concrete self-weight. Similar to other pozzolanic materials, such as silica fume and fly ash, substitution with zeolite can improve the strength of concrete via the pozzolanic reaction with $\mathrm{Ca}(\mathrm{OH})_{2}$. It can reduce the bleeding, segregation, and delamination of fresh concrete, facilitate pumping processes, decrease the permeability of hardened concrete, enhance durability (especially alkaliaggregate reactivity), increase concrete strength, and minimize the cracking in concrete caused by autogenous-shrinkage.

Expanded clays are made of clays that may expand up to 5-6 folds, by volume as a result of gas release when they are treated with heat. A hard sintered crust is formed on the outer surface, while quite light and highly durable aggregate with a porous clinker-like structure may be produced inside it [18]. Expanded clay aggregates are a new topic for Turkey and detailed studies on their production have begun recently [19]. Expanded clay aggregates are used in many different industries due to their useful technical features and numerous advantages when compared to many other industrial raw materials [19]. One of the materials that yield the greatest concrete compressive strength among lightweight aggregates is expanded clay aggregate. This gives it a significant position in the construction industry. Because LCHC reduces walls dead load comparing with conventional masonry elements, reductions up to $20 \%$ in reinforcing steel weight may be gained while up to $50 \%$ may be saved in heating-cooling expenses in buildings containing components made with expanded clay aggregates in Turkey $[18,20]$. They have high porosity and low density. The bubbly nature of expanded clay aggregate is due to liberation of gases during calcination. They are typically brown and reddish in colour due to their high iron contents. The surface of some expanded clay aggregates may have a yellowish iridescent colour based on the pellet admixture materials.

Diatomite is a biochemical sedimentary white-or cream-colored, friable, porous rock mainly composed of the fossilized remains of unicellular fresh water plants known as diatoms. Diatoms are tiny plants that float near the ocean surface. Their skeletons are composed of silica, a very durable substance. Since diatom skeletons are highly porous, diatomite has extremely low density, and pure samples make excellent water filters. Chemically inert and having a rough texture and other unusual physical properties, it is suitable for many scientific and industrial purposes, including use as a filtering agent; building material; heat, cold, and sound insulator; catalyst carrier; filler absorbent; abrasive; and ingredient in pharmaceutical preparations $[21,22,23]$.

\subsection{Mix Design and Sample Preparation}

In order to analyse the use of quaternary blends containing volcanic tuff, expanded clay aggregate, diatomite and cement to produce LCHC blocks for walls and partitions, initially 28 different mixture proportions (M1-M28) by mass and cement contents of 94.5, 121.5 and $162.5 \mathrm{~kg} / \mathrm{m}^{3}$ were adopted for the concrete mixture batches, respectively. Drying shrinkage and wetting expansion are major weaknesses in volcanic tuff powder based blocks. In low slump lightweight masonry hollow blocks, drying shrinkage cracking can be minimized by keeping the water/binder ratio as low as possible [2]. Hence, in the present study, $30 \mathrm{~mm}$ slump value was used as the limit for the dry consistency mixture. 
Table 4 - Proportions of trial mixtures (\% by apparent volume*, av\%)

\begin{tabular}{|c|c|c|c|c|c|}
\hline Mix & CEM I & VTP & ECA & FDA & CDA \\
\hline M1 & 9.00 & 1.00 & 90.00 & - & - \\
\hline M2 & 9.00 & 3.00 & 88.00 & - & - \\
\hline M3 & 9.00 & 5.00 & 86.00 & - & - \\
\hline M4 & 7.00 & - & 15.00 & 39.00 & 39.00 \\
\hline M5 & 7.00 & - & 20.00 & 36.50 & 36.50 \\
\hline M6 & 7.00 & - & 25.00 & 34.00 & 34.00 \\
\hline M7 & 9.00 & - & 15.00 & 38.00 & 38.00 \\
\hline M8 & 9.00 & - & 20.00 & 35.50 & 35.50 \\
\hline M9 & 9.00 & - & 25.00 & 33.00 & 33.00 \\
\hline M10 & 12.00 & - & 15.00 & 36.50 & 36.50 \\
\hline M11 & 12.00 & - & 20.00 & 34.00 & 34.00 \\
\hline M12 & 12.00 & - & 25.00 & 31.50 & 31.50 \\
\hline M13 & 7.00 & 1.00 & 20.00 & 36.00 & 3600 \\
\hline M14 & 7.00 & 3.00 & 20.00 & 35.00 & 35.00 \\
\hline M15 & 7.00 & 5.00 & 20.00 & 34.00 & 34.00 \\
\hline M16 & 12.00 & 1.00 & 20.00 & 33.50 & 33.50 \\
\hline M17 & 12.00 & 3.00 & 20.00 & 32.50 & 32.50 \\
\hline M18 & 12.00 & 5.00 & 20.00 & 31.50 & 31.50 \\
\hline M19 & 7.00 & 3.00 & 15.00 & 22.50 & 52.50 \\
\hline M20 & 7.00 & 3.00 & 20.00 & 21.00 & 49.00 \\
\hline M21 & 7.00 & 3.00 & 25.00 & 19.50 & 45.50 \\
\hline M22 & 9.00 & 3.00 & 15.00 & 21.90 & 51.10 \\
\hline M23 & 9.00 & 3.00 & 20.00 & 20.40 & 47.60 \\
\hline M24 & 9.00 & 3.00 & 25.00 & 18.90 & 44.10 \\
\hline M25 & 12.00 & 3.00 & 15.00 & 21.00 & 49.00 \\
\hline M26 & 12.00 & 3.00 & 20.00 & 19.50 & 45.50 \\
\hline M27 & 12.00 & 3.00 & 25.00 & 18.00 & 42.00 \\
\hline M28 & 9.00 & - & 91.00 & - & - \\
\hline
\end{tabular}

* Apparent volume is defined as the ratio mass to the dry particle density.

The first three trial batches were undertaken to determine mean strength and unit mass values of concrete mixtures containing VTP and ECA aggregate. To this effect, basically the first three preliminary batches were designed with aggregate/cement $(\mathrm{A} / \mathrm{C})$ ratios of $7: 1$ to $7.5: 1$ by mass with $9 \%$ CEM I content by volume in a range of $12.4-62.0 \mathrm{~kg} / \mathrm{m}^{3}$ VTP contents without any diatomite aggregates. These batches were used as the control mixtures throughout the research. In order to evaluate the density, water absorption and strength requirement for lightweight concrete design in masonry block production, the effect of diatomite aggregates as ingredients was also analysed by a series of trial batches. For this purpose, additional preliminary batches were designed with aggregate/cement ratios of 2.5:1 
to $5.5: 1$ by mass in a range of $94.5-162.0 \mathrm{~kg} / \mathrm{m}^{3}$ CEM I contents using fine and coarse diatomite aggregates at different percentages by apparent volume. The mixtures proportions for trial batches are given in Table 4 in terms of dry masses of the ingredients. Concrete design methodology was constructed according to TS EN 771-3 standard. Information and results derived from these trial mixtures were used to produce main relationship; linking various parameters to both $\mathrm{A} / \mathrm{C}$ ratio and cement content. Test results of these trial batches are given in Table 5. All trials were conducted using CEM I of local manufacture, complying with the requirements of ASTM Type I $\left(42.5 \mathrm{~N} / \mathrm{mm}^{2}\right)$ cement.

Table 5 - Physical characteristics of the $100 \mathrm{~mm}$-cube specimens

\begin{tabular}{|c|c|c|c|}
\hline Mix & $\begin{array}{l}\text { Dry density } \\
\left(\mathrm{kg} / \mathrm{m}^{3}\right)\end{array}$ & $\begin{array}{l}\text { Compressive strength } \\
\left(\mathrm{N} / \mathrm{mm}^{2}\right)\end{array}$ & $\begin{array}{l}\text { Water absorption } \\
\text { (\% by weight) }\end{array}$ \\
\hline M1 & 1114 & 3.82 & 17.23 \\
\hline M2 & 1119 & 4.53 & 16.82 \\
\hline M3 & 1125 & 5.36 & 15.37 \\
\hline M4 & 582 & 1.74 & 31.71 \\
\hline M5 & 615 & 1.80 & 30.40 \\
\hline M6 & 649 & 1.87 & 29.26 \\
\hline M7 & 604 & 2.29 & 26.97 \\
\hline M8 & 637 & 2.37 & 25.37 \\
\hline M9 & 670 & 2.46 & 23.12 \\
\hline M10 & 636 & 3.16 & 21.47 \\
\hline M11 & 669 & 3.27 & 21.58 \\
\hline M12 & 703 & 3.39 & 21.47 \\
\hline M13 & 625 & 2.09 & 29.86 \\
\hline M14 & 644 & 2.38 & 28.45 \\
\hline M15 & 663 & 2.67 & 26.29 \\
\hline M16 & 679 & 3.59 & 19.93 \\
\hline M17 & 698 & 3.92 & 19.02 \\
\hline M18 & 717 & 4.26 & 15.02 \\
\hline M19 & 596 & 2.22 & 28.04 \\
\hline M20 & 631 & 2.35 & 27.66 \\
\hline M21 & 665 & 2.47 & 25.69 \\
\hline M22 & 618 & 2.79 & 23.93 \\
\hline M23 & 653 & 2.94 & 23.28 \\
\hline M24 & 687 & 3.08 & 23.20 \\
\hline M25 & 651 & 3.69 & 20.49 \\
\hline M26 & 686 & 3.87 & 20.16 \\
\hline M27 & 720 & 4.05 & 18.52 \\
\hline M28 & 1111 & 3.66 & 17.85 \\
\hline
\end{tabular}


BS 1881: Part 125 [24] was followed for mixing and sampling the fresh concrete in laboratory and BS 1881: Part 114 [25] was followed for measuring the density of hardened concrete. According to the preliminary trial batch results, the fines content for optimum plastic properties in the fresh concrete and the final mixture compositions for the concrete work were determined. Cube specimens of $100 \mathrm{~mm}$ size were used for testing the mixture strengths and the effectiveness of fines content in the preliminary trials. A cellular hollow block form conforming the specifications of BS 6073: Part 1 [26] standard was used for preparation of LCHC specimens. The ratio of solid area and the total solid volume of the hollow block form are the same $(77.65 \%)$ due to the blocks' being open sub-section type. The web and shell thicknesses of the block are $22 \mathrm{~mm}$ and the block dimensions are $195 \mathrm{~mm}$ in height, $390 \mathrm{~mm}$ in length and $190 \mathrm{~mm}$ in width. For each mixture, 24 block specimens were cast and compacted on a vibration machine. The specimens were then air cured at $22 \pm 3^{\circ} \mathrm{C}$ temperature and $50 \pm 5 \%$ relative humidity up to 28 days until the time of testing. The samples were then tested in air dry condition for compressive strength in accordance with BS 6073: Part 1 [26].

\section{RESULTS AND DISCUSSIONS}

Tuff and diatomite have an ability of high water absorption due to their high porosity and particle size distribution, therefore, the experience of block making machine operator is of critical importance in controlling the water content of lightweight concrete during mixing, unless a sufficiently accurate automatic control system and procedure is available. Any variation in water content and effective water/binder ratio will result in variations in the rate of strength gain and final strength. On the other hand, due to their low water absorption capacity, expanded clay aggregates are more suitable as compared to tuff and diatomite aggregates for concrete mixing for block making.

\subsection{The Effect of VTP as a Natural Pozzolan}

Many recent studies have examined the feasibility of using volcanic tuff as lightweight aggregate, building stone, and pozzolans in cements and concretes [3, 4, 27, 28].

The natural pozzolan used in this study was obtained from the location of ignimbrite Mining Quarry in Aksaray Region, Central Turkey. It is a highly porous, lightweight, finely divided mineral material containing large quantities of amorphous $\mathrm{SiO}_{2}$ and $\mathrm{Al}_{2} \mathrm{O}_{3}$. Although the bulk density of VTP as a natural aggregate is in the range of $850-1200 \mathrm{~kg} / \mathrm{m}^{3}$, the bulk density of fine grade VTP is in the range of $1200-1300 \mathrm{~kg} / \mathrm{m}^{3}$, which is a typical lightweight aggregate block density range and the relevant mineralogical properties. In practice, VTP is used in ratios from $1 \%$ to $7 \%$ by apparent volume of lightweight concrete mixtures as a strength enhancer material. However, more than $7 \%$ of VTP by apparent volume in LCHC is known to reduce the compressive strength. Therefore, in this research work, the VTP content was set lower than $7 \%$ by apparent volume. Table 6 gives the limits of VTP and lightweight aggregate contents for use in LCHC. It has been shown experimentally that lightweight concretes containing expanded clay aggregate and natural pozzolan have relatively higher sulphate resistance, higher strength and durability. On the other hand, addition of a large quantity of the natural pozzolan decreases the compressive strength of concrete; therefore, an optimum quantity is necessary to achieve the maximum compressive 
strength. Finely grounded VTP is mostly used with another porous aggregate. The basic effect of finely grounded VTP on fresh concrete is to improve cohesion, which prevents segregation, enhances mould filling, compaction, eases demoulding and modifies the texture improving the finish of fine quality blocks.

\section{Table 6 - Standard requirements for lightweight aggregates for masonry and structural concrete}

\begin{tabular}{ll}
\hline BS 3797 requirements & Maximum Limits \\
Loss on ignition-masonry units & $25 \%$ \\
Reinforced and high durability concrete & $10 \%$ \\
\hline
\end{tabular}

The use of tuff as natural pozzolan in lightweight concrete can also reduce the expenses if early strength is not important. BS 6073:Part 1 [26] requires a minimum strength of 2.8 $\mathrm{N} / \mathrm{mm}^{2}$ at 28 days with no individual block strength lower than $80 \%$ of that value.

A series of LCHC blocks were produced with different proportions of tuff powder, expanded clay aggregate, diatomite and cement. The results of a comprehensive experimental research work carried out are presented in Figures $2-9$ and Table 7 showing the mean values of each mixture.

Concretes containing tuff powders are generally expected to exhibit less bleeding and segregation than plain concretes. This effect makes the use of tuff powder particularly valuable in concrete mixtures made with aggregates that are deficient in fines. The reduction in bleed water could be primarily due to the reduced water demand in powder tuff concretes.

Table 7 - Mixture proportions and physical properties of hollow blocks (mean values of 24 specimens for each mix)

\begin{tabular}{|c|c|c|c|c|c|c|c|c|c|c|c|}
\hline Mix & $\mathrm{A} / \mathrm{C}$ & $\begin{array}{l}\text { CEM I } \\
\left(\mathrm{kg} / \mathrm{m}^{3}\right)\end{array}$ & $\begin{array}{l}\text { VTP } \\
\left(\mathrm{kg} / \mathrm{m}^{3}\right)\end{array}$ & $\begin{array}{l}\text { ECA } \\
\left(\mathrm{kg} / \mathrm{m}^{3}\right)\end{array}$ & $\begin{array}{l}\text { FDA } \\
\left(\mathrm{kg} / \mathrm{m}^{3}\right)\end{array}$ & $\begin{array}{l}\text { CDA } \\
\left(\mathrm{kg} / \mathrm{m}^{3}\right)\end{array}$ & $\mathrm{W} / \mathrm{C}$ & $\begin{array}{l}\text { Dry } \\
\text { block } \\
\text { mass } \\
(\mathrm{kg})\end{array}$ & $\begin{array}{l}\text { Dry } \\
\text { density of } \\
\text { hollow } \\
\text { block } \\
\left(\mathrm{kg} / \mathrm{m}^{3}\right)\end{array}$ & $\begin{array}{l}\text { Water } \\
\text { absorption } \\
\text { of hollow } \\
\text { block } \\
\left(\mathrm{kg} / \mathrm{m}^{3}\right)\end{array}$ & $\begin{array}{l}\text { Compressi } \\
\text { ve strength } \\
\text { of hollow } \\
\text { block } \\
\left(\mathrm{N} / \mathrm{mm}^{2}\right)\end{array}$ \\
\hline M1 & 7.3 & 121.5 & 12.4 & 878.40 & - & - & 3.97 & 11.86 & 865 & 161.94 & 2.96 \\
\hline M2 & 7.4 & 121.5 & 37.2 & 858.88 & - & - & 3.95 & 11.91 & 869 & 158.67 & 3.52 \\
\hline M3 & 7.4 & 121.5 & 62.0 & 839.36 & - & - & 3.91 & 11.98 & 874 & 145.63 & 4.16 \\
\hline M4 & 4.6 & 94.5 & - & 146.40 & 161.07 & 127.14 & 3.25 & 6.20 & 452 & 167.31 & 1.35 \\
\hline M5 & 4.9 & 94.5 & - & 195.20 & 150.75 & 118.99 & 3.21 & 6.55 & 478 & 167.43 & 1.40 \\
\hline M6 & 5.2 & 94.5 & - & 244.00 & 140.42 & 110.84 & 3.26 & 6.91 & 504 & 168.22 & 1.45 \\
\hline M7 & 3.5 & 121.5 & - & 146.40 & 156.94 & 123.88 & 2.08 & 6.43 & 469 & 156.14 & 1.78 \\
\hline M8 & 3.8 & 121.5 & - & 195.20 & 146.62 & 115.73 & 2.63 & 6.78 & 495 & 152.55 & 1.84 \\
\hline M9 & 4.0 & 121.5 & - & 244.00 & 136.29 & 107.58 & 2.68 & 7.13 & 520 & 144.22 & 1.91 \\
\hline M10 & 2.6 & 162.0 & - & 146.40 & 150.75 & 118.99 & 2.18 & 6.77 & 494 & 142.04 & 2.45 \\
\hline M11 & 2.8 & 162.0 & - & 195.20 & 140.42 & 110.84 & 2.13 & 7.12 & 519 & 147.17 & 2.54 \\
\hline M12 & 2.9 & 162.0 & - & 244.00 & 130.10 & 102.69 & 2.16 & 7.48 & 546 & 151.16 & 2.63 \\
\hline
\end{tabular}


Table 7 - Mixture proportions and physical properties of hollow blocks (mean values of 24 specimens for each mix) (continue)

\begin{tabular}{llllllllllll}
\hline Mix & A/C & $\begin{array}{l}\text { CEM I } \\
\left(\mathrm{kg} / \mathrm{m}^{3}\right)\end{array}$ & $\begin{array}{l}\text { VTP } \\
\left(\mathrm{kg} / \mathrm{m}^{3}\right)\end{array}$ & $\begin{array}{l}\text { ECA } \\
\left(\mathrm{kg} / \mathrm{m}^{3}\right)\end{array}$ & $\begin{array}{l}\text { FDA } \\
\left(\mathrm{kg} / \mathrm{m}^{3}\right)\end{array}$ & $\begin{array}{l}\mathrm{CDA} \\
\left(\mathrm{kg} / \mathrm{m}^{3}\right)\end{array}$ & $\mathrm{W} / \mathrm{C}$ & $\begin{array}{l}\text { Dry } \\
\text { block } \\
\text { mass } \\
(\mathrm{kg})\end{array}$ & $\begin{array}{l}\text { Dry } \\
\text { density of } \\
\text { hollow } \\
\text { block } \\
\left(\mathrm{kg} / \mathrm{m}^{3}\right)\end{array}$ & $\begin{array}{l}\text { Water } \\
\text { absorption } \\
\text { of hollow } \\
\text { block } \\
\left(\mathrm{kg} / \mathrm{m}^{3}\right)\end{array}$ & $\begin{array}{l}\text { Compressi } \\
\text { ve strength } \\
\text { of hollow } \\
\text { block } \\
\left(\mathrm{N} / \mathrm{mm}^{2}\right)\end{array}$ \\
\hline M13 & 5.0 & 94.5 & 12.4 & 195.20 & 148.68 & 117.36 & 3.23 & 6.65 & 485 & 166.61 & 1.62 \\
M14 & 5.2 & 94.5 & 37.2 & 195.20 & 144.55 & 114.10 & 3.35 & 6.86 & 500 & 162.53 & 1.85 \\
M15 & 5.4 & 94.5 & 62.0 & 195.20 & 140.42 & 110.84 & 3.48 & 7.06 & 515 & 153.73 & 2.08 \\
M16 & 2.8 & 162.0 & 12.4 & 195.20 & 138.36 & 109.21 & 2.03 & 7.23 & 527 & 137.25 & 2.79 \\
M17 & 2.9 & 162.0 & 37.2 & 195.20 & 134.23 & 105.95 & 2.11 & 7.43 & 542 & 133.28 & 3.04 \\
M18 & 3.0 & 162.0 & 62.0 & 195.20 & 130.10 & 102.69 & 2.18 & 7.63 & 557 & 107.07 & 3.31 \\
M19 & 4.7 & 94.5 & 37.2 & 146.40 & 92.93 & 171.15 & 3.40 & 6.34 & 463 & 150.69 & 1.73 \\
M20 & 5.1 & 94.5 & 37.2 & 195.20 & 86.73 & 159.74 & 3.39 & 6.72 & 490 & 155.47 & 1.82 \\
M21 & 5.4 & 94.5 & 37.2 & 244.00 & 80.54 & 148.33 & 3.44 & 7.08 & 516 & 150.58 & 1.92 \\
M22 & 3.6 & 121.5 & 37.2 & 146.40 & 90.45 & 166.59 & 2.72 & 6.58 & 480 & 140.75 & 2.17 \\
M23 & 3.9 & 121.5 & 37.2 & 195.20 & 84.25 & 155.18 & 2.65 & 6.95 & 507 & 142.54 & 2.28 \\
M24 & 4.1 & 121.5 & 37.2 & 244.00 & 78.06 & 143.77 & 2.67 & 7.31 & 533 & 147.45 & 2.39 \\
M25 & 2.7 & 162.0 & 37.2 & 146.40 & 86.73 & 159.74 & 2.12 & 6.93 & 506 & 137.45 & 2.87 \\
M26 & 2.8 & 162.0 & 37.2 & 195.20 & 80.54 & 148.33 & 2.06 & 7.30 & 533 & 139.73 & 3.01 \\
M27 & 3.0 & 162.0 & 37.2 & 244.00 & 74.34 & 136.92 & 2.07 & 7.66 & 559 & 132.39 & 3.15 \\
M28 & 7.3 & 121.5 & - & 886.16 & - & - & 4.02 & 11.83 & 863 & 167.45 & 2.84 \\
\hline & & & & & & & & & & &
\end{tabular}

\subsection{Compressive Strength and LCHC Unit Density}

Filling and partitioning, non-load bearing walls seem to be the main building domain of application of lightweight concrete masonry units made of LCHC. Therefore, lightness, material integrity, adequate durability, good thermal and acoustic insulation ability, cost and sustainability, are some expected material properties [29]. LCHC blocks are a non-structural element and the blocks for non-load bearing applications. However, it is important that this type of masonry unit presents a certain compressive strength. For instance, it has to be able to support the weight of the overlying portion of the wall. Additionally, an adequate compressive strength also indicates that the concrete masonry unit presents an acceptable material integrity and therefore, it can be shipped, stored and applied in the building site [29]. BS EN 771-3:2011 sets the range for the compressive strengths of concrete masonry units (with dense and/or lightweight aggregates) from $2.9 \mathrm{~N} / \mathrm{mm}^{2}$ to $10.4 \mathrm{~N} / \mathrm{mm}^{2}$ [30]. It is wellknown that, in general, strength increases with increasing un density. On the other hand, regardless of unit density, all non-load bearing concrete masonry units meeting the physical properties required by BS 6073: Part 1 [26] are required to have a minimum average compressive strength of $2.8 \mathrm{~N} / \mathrm{mm}^{2}$ with no individual block lower than $80 \%$ of that value, as noted in Section 3.1 above, for minimum building and service functionality. Concrete strength is affected by many factors, such as properties of constituent materials, water/cement ratio, coarse/fine aggregate ratio, age of concrete, compaction of concrete, temperature, relative humidity and curing of concrete. In addition to these, some factors affecting the compressive strength of a lightweight masonry blocks are shape and dimension of the unit, 
and aggregate types used in mixtures. Some of these parameters are evaluated for analysing the compressive strength properties of lightweight masonry blocks.

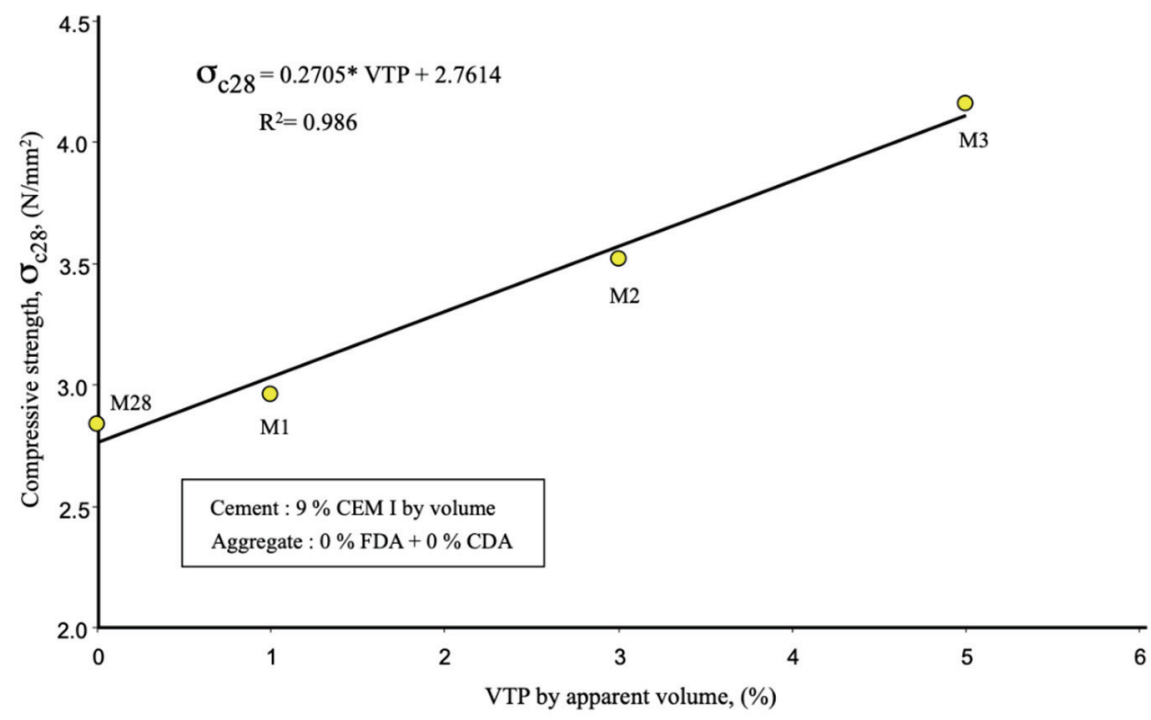

Figure 2 - The 28-day compressive strength versus VTP content of hollow blocks

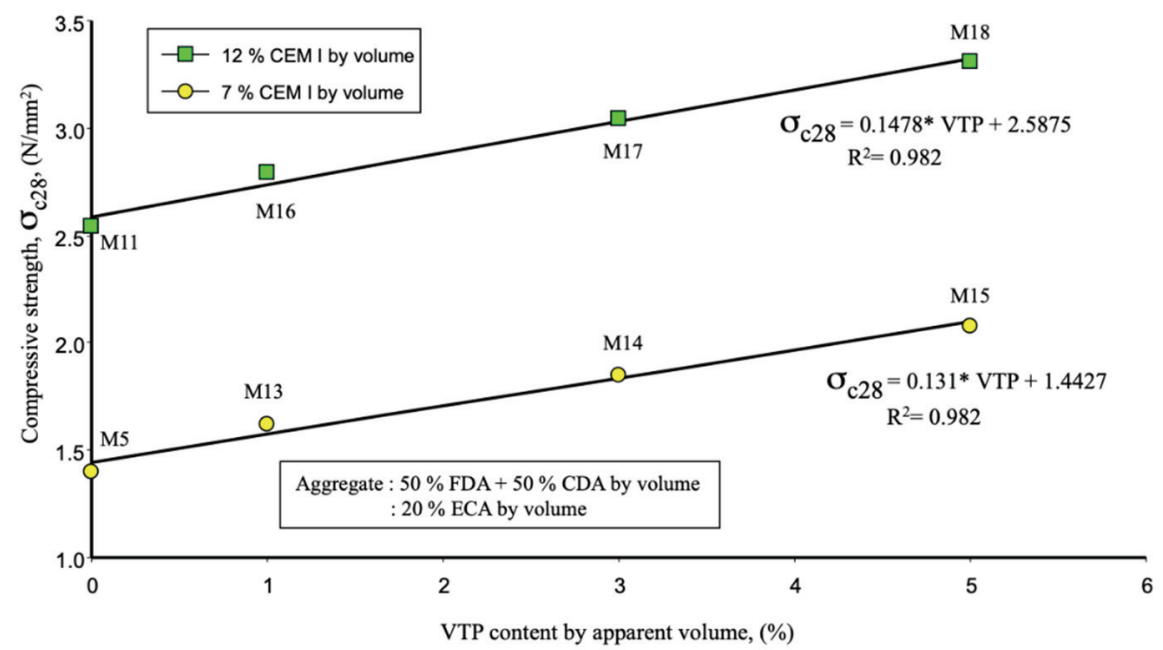

Figure 3 - The 28-day compressive strength versus VTP content of hollow blocks

Figure 2 shows the mean values of 28-day compressive strengths of LCHC blocks with a constant CEM I content of $9 \%$ by volume with only VTP and ECA. As represented in Fig. 
2, the compressive strength of LCHC blocks shows a linearly increasing trend with increasing VTP content. An increase of $2 \%$ VTP content provides approximately $18.5-19.0 \%$ strength increase in blocks containing ECA. However, the density of LCHC blocks increase by approximately $0.5 \%$ due to the increase in VTP content, which could be considered negligible for lightweight masonry blocks. All the mixtures with $9 \%$ CEM I content by volume produced with only VTP and ECA aggregates comply with the strength requirement of BS 6073.

Figure 3, shows the compressive strengths of LCHC blocks with $7 \%$ and $12 \%$ CEM I, constant $20 \%$ VTP contents by apparent volume, and the remaining $73 \%$ to $68 \%$ by apparent volume being completed by adding a $50 \%$ FDA $+50 \%$ CDA mixture. Addition of FDA and CDA in the lightweight concrete mixtures reduces the strength of masonry blocks compared to those with only VTP and ECA. The results show that the cement content is an important factor affecting the required strength in mixtures. As represented in Fig.3, for the mix with $7 \%$ CEM I content, the compressive strength of LCHC blocks increases with increasing VTP content of $1 \%, 3 \%$ and $5 \%$ by apparent volume. However, not all the mixtures with $7 \%$ CEM I comply with the average strength requirement of BS 6073 . On the other hand, the mean compressive strength values of LCHC blocks with a constant CEM I content of $12 \%$ are higher than those of $7 \%$ CEM I mixtures and the use of VTP equal to or more than $1 \%$ by apparent volume seems to be sufficient to meet the minimum average strength requirement of BS 6073: Part 1 for masonry blocks. Although using more VTP increases the strength, dry densities of the blocks also increase, as given in Table 7.

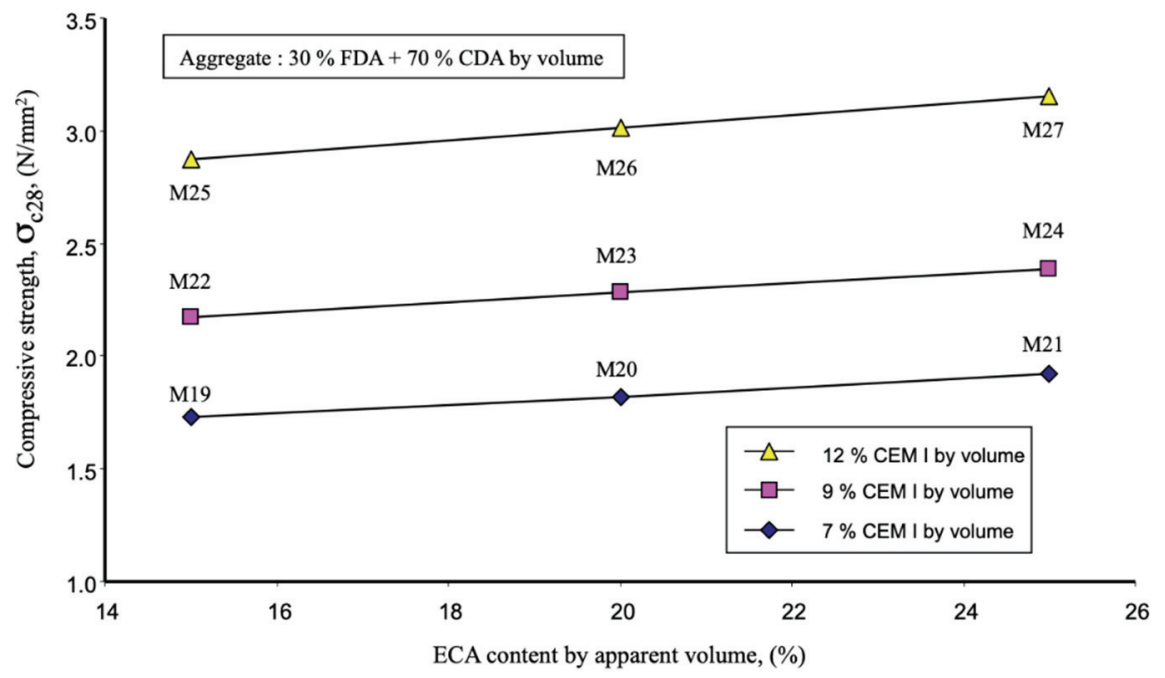

Figure 4 - The 28-day compressive strength versus ECA content by apparent volume for hollow blocks

Figure 4 shows the compressive strength versus ECA content of LCHC blocks containing FDA and CDA mixtures of $30 \%$ FDA $+70 \%$ CDA by apparent volume and with only a constant $3 \%$ VTP as an additive. Fig. 4 indicates that the compressive strengths of LCHC 
blocks increases with increasing in ECA contents depending on the CEM I content. However, only up to $12 \%$ CEM I content blocks meet the minimum average strength requirement of $2.8 \mathrm{~N} / \mathrm{mm}^{2}$. The minimum average crushing strength prescribed in BS 6073: Part 1 [26] is $2.8 \mathrm{~N} / \mathrm{mm}^{2}$. Therefore, these blocks can easily be used with $12 \%$ OCEM I content by volume for the purpose of non-load bearing building applications. However, the research showed that the compressive strength of LCHC blocks without VTP attain only very low strength values. Fig. 5 illustrates low average strengths of LCHC blocks made with concretes containing 15, $20,25 \%$ ECA and appropriate amounts of $50 \%$ FDA $+50 \%$ CDA mixtures did not attain the required strength as experienced in the mixes with $7 \%, 9 \%$ and $12 \%$ CEM I, no VTP and the remaining volume completed with appropriate amounts of $30 \%$ FDA $+70 \%$ CDA by apparent volume. Although the dry block densities are much lower, all the mixes (M4 to M15) with appropriate quantities of $50 \%$ FDA $+50 \%$ CDA mixtures added to sum up to $100 \%$ by apparent volume did not meet the strength requirement.

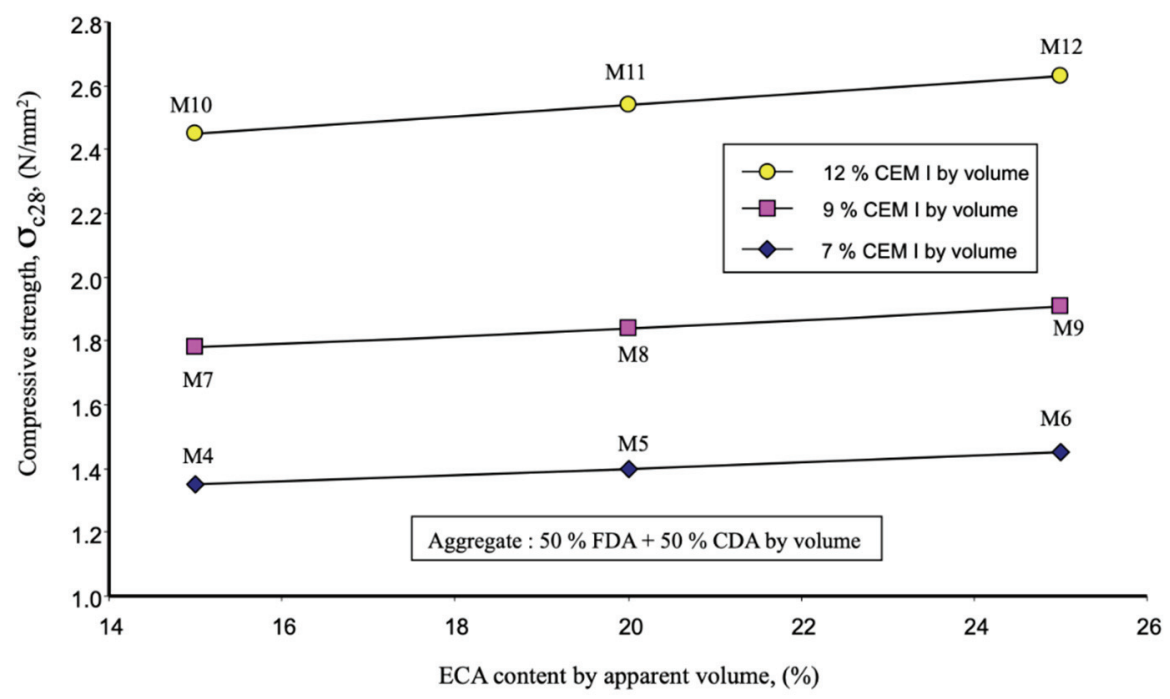

Figure 5 - The 28-day mean compressive strength versus ECA content by apparent volume for hollow blocks

The use of larger maximum size of aggregate affects the strength in several ways. Firstly, since larger aggregates have less specific surface area and the aggregate-paste bond strength is less, concrete fails along surfaces of the coarse aggregates resulting in reduced compressive strength of masonry concrete. Secondly, when a uniform grain size distribution is used, the smaller grains can be found among the larger grains. In this way, the gap volume and thus the need for cement paste is reduced. When the larger grain size is used, the volume of the gap between aggregates and the surface of the aggregate that need to be wrapped with cement paste are reduced. For a given volume of concrete, using larger aggregate particle size results in a smaller volume of cement matrix as the contact surfaces between the aggregates and cement paste will decrease, thereby providing more restraint to volume changes of the cement matrix. This may induce additional stresses in the matrix, creating microcracks prior to 
application of load, which may be a critical factor in very high strength concretes [31]. Therefore, it is the general consensus that optimum size aggregates should be well investigated to produce masonry concrete mixtures of sufficient strength. Findings of this experimental research showed that the optimum aggregate size should not exceed $8 \mathrm{~mm}$ for masonry block concrete mixtures containing diatomite aggregates.

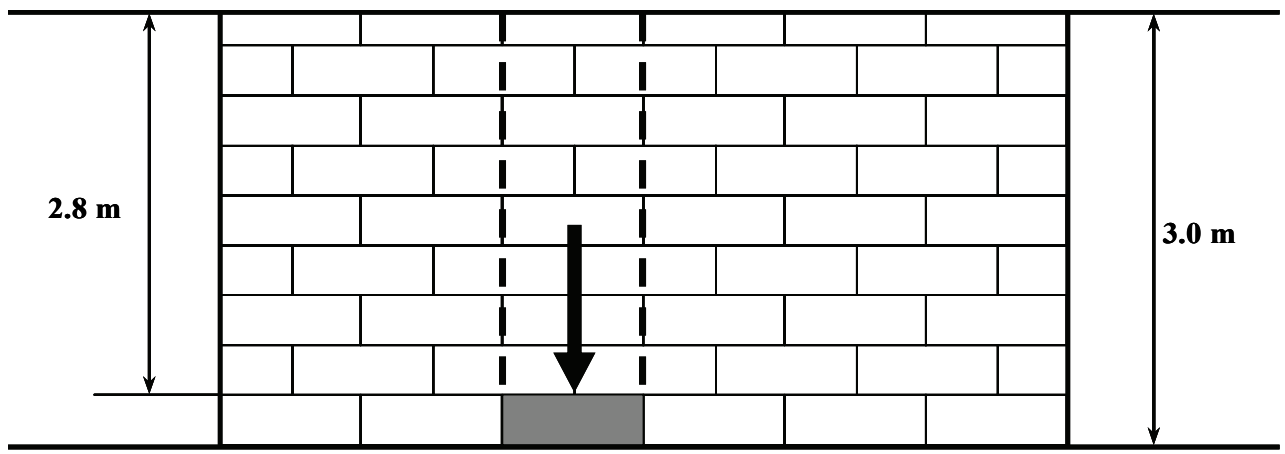

Figure 6 - Dead load acting on a critical lightweight concrete masonry block

The research results showed that some of the LCHC blocks have compressive strengths too low for masonry block application such as M10, M11, M12, M22, M23 and M24 etc. as shown in Table 7. Compressive strength values of these blocks, ranging from $2.17 \mathrm{~N} / \mathrm{mm}^{2}$ to $2.63 \mathrm{~N} / \mathrm{mm}^{2}$, are lower than $2.8 \mathrm{~N} / \mathrm{mm}^{2}$, the minimum LCHC block average compressive strength admissible by BS 6073 . On the other hand, the obtained compressive strength values of LCHC blocks may still be acceptable in the context of lightweight masonry units. For instance, in a $3 \mathrm{~m}$ high wall built with LCHC blocks, the masonry units placed at the first layer (critical ones) will be under an approximate stress of $0.03 \mathrm{MPa}$ compressive stress corresponding to the dead load related to the weight of the overlying wall as shown in Fig. 6. On the other hand, the obtained experimental ultimate compressive strength of the weakest LCHC blocks was $1.35 \mathrm{MPa}$ which is significantly higher than $0.03 \mathrm{MPa}$. Therefore, the proposed LCHC blocks may have an acceptable mechanical behaviour in the context of lightweight concrete masonry units for non-load bearing applications.

The density of a lightweight concrete masonry block is expressed as the oven-dry density of concrete in $\mathrm{kg} / \mathrm{m}^{3}$ as determined in accordance with ASTM C 140: Standard Test Methods for Sampling and Testing Concrete Masonry Units and Related Units. In production, the density of a given concrete masonry unit is controlled in part by the methods used to manufacture the unit, but largely by the type of aggregate used in production [32]. Through the use of lightweight aggregates, the resulting density of lightweight concrete masonry units can be varied by the producer to achieve one or more desired physical properties. Block dry density, however, can influence other structural design considerations, aside from compressive strength. Reducing the density of a concrete masonry unit can reduce the overall weight of a structure, and potentially reduce the required size of the supporting foundation and the structural members. Reducing the mass of a structure or element also reduces the seismic load a structure or element must be designed to resist, because the magnitude of seismic loading is a direct function of dead load [32]. 


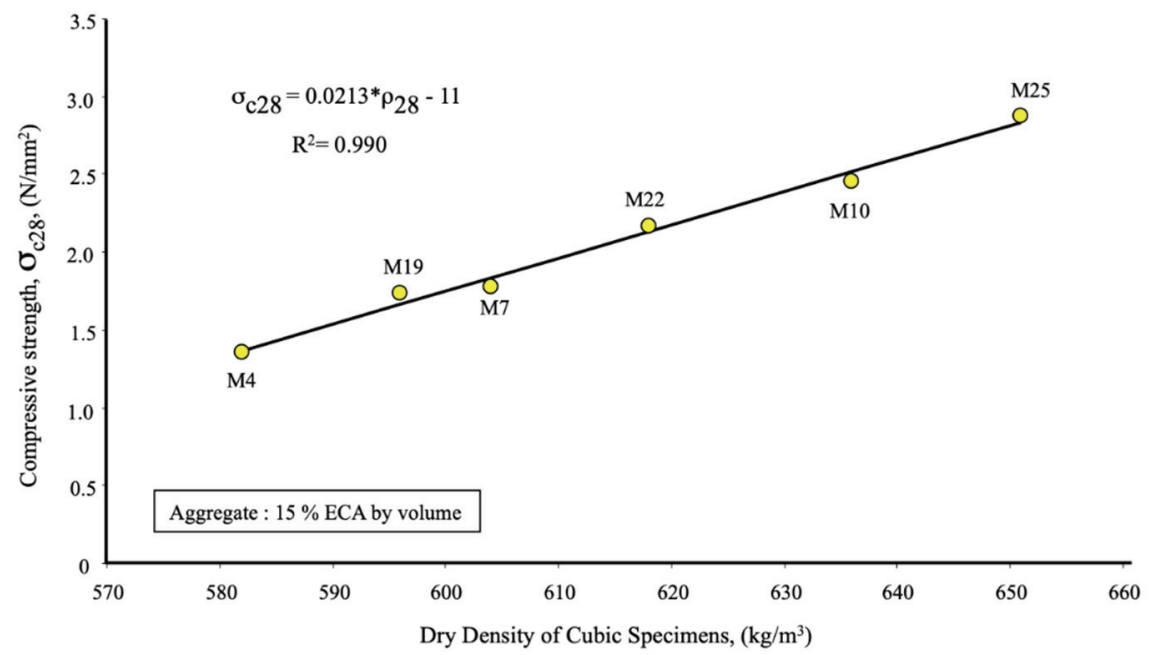

Figure 7 - The 28-day mean compressive strength of hollow blocks versus dry density of cubic specimens

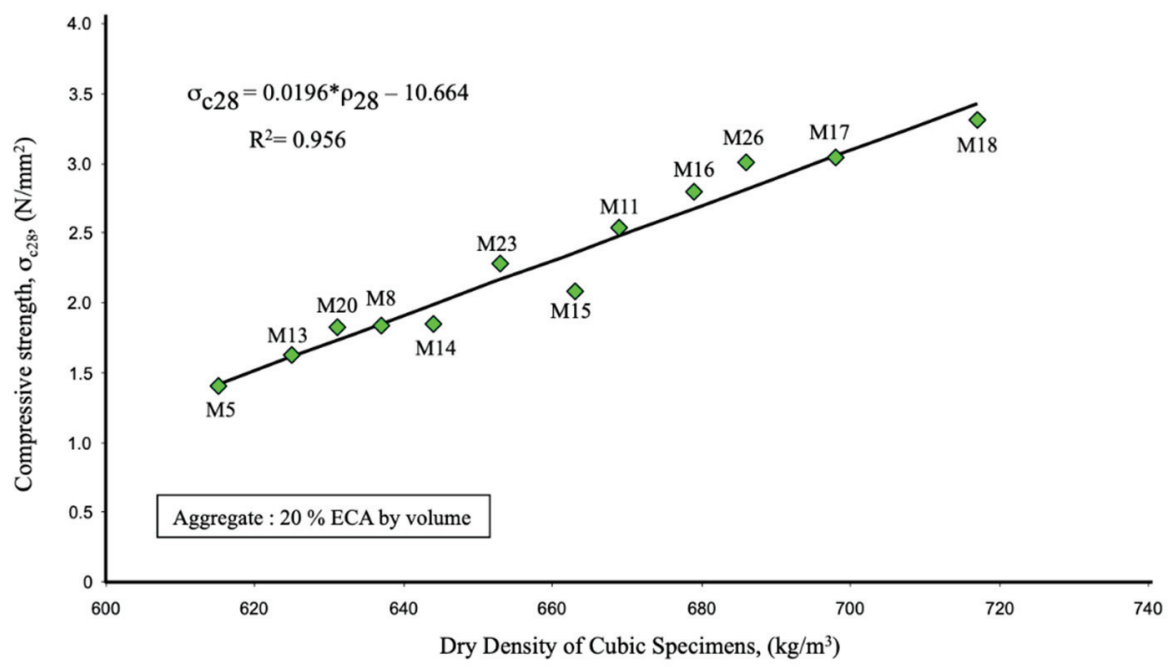

Figure 8 - The 28-day mean compressive strength of hollow blocks versus dry density of cubic specimens

In general, for a given concrete masonry unit mix design, higher compressive strengths can be achieved by increasing the unit density through adjustments to the manufacturing methods. [33]. Therefore, some correlations could be statistically developed for dry density versus compressive strength of the blocks according to constituent aggregate characteristics. 
The difference in dry densities of LCHC blocks made with various proportions of VTP and ECA when cured in air environment condition is also presented in Table 7. Figs. 7-9 show relationships between dry density of hollow blocks and their mean compressive strength values at 28 days of curing time for $15 \%, 20 \%$ and $25 \%$ ECA content by volume, respectively. As indicated in Figs. 7-9, increase of dry density of hollow blocks increases the compressive strength for all evaluations, too. However, the increase of $5 \%$ ECA in use causes $5.5 \%$ density reduction of masonry blocks on the average. The results indicate that LCHC blocks with high proportions of diatomite aggregates have less density compared to hollow blocks without diatomite aggregates. The difference of block dry density rate is almost near to $50 \%$ with and without diatomite aggregates. It is evident from Table 7 that, the loss in dry block density is found to be as $46.5 \%$ for $50 \%$ FDA $+50 \%$ CDA by apparent volume batches and $44.8 \%$ for $30 \%$ FDA $+70 \%$ CDA by apparent volume batches, respectively. It is also observed that reduction in $\mathrm{W} / \mathrm{C}$ ratio results in increase in the compressive strength of the LCHC blocks.

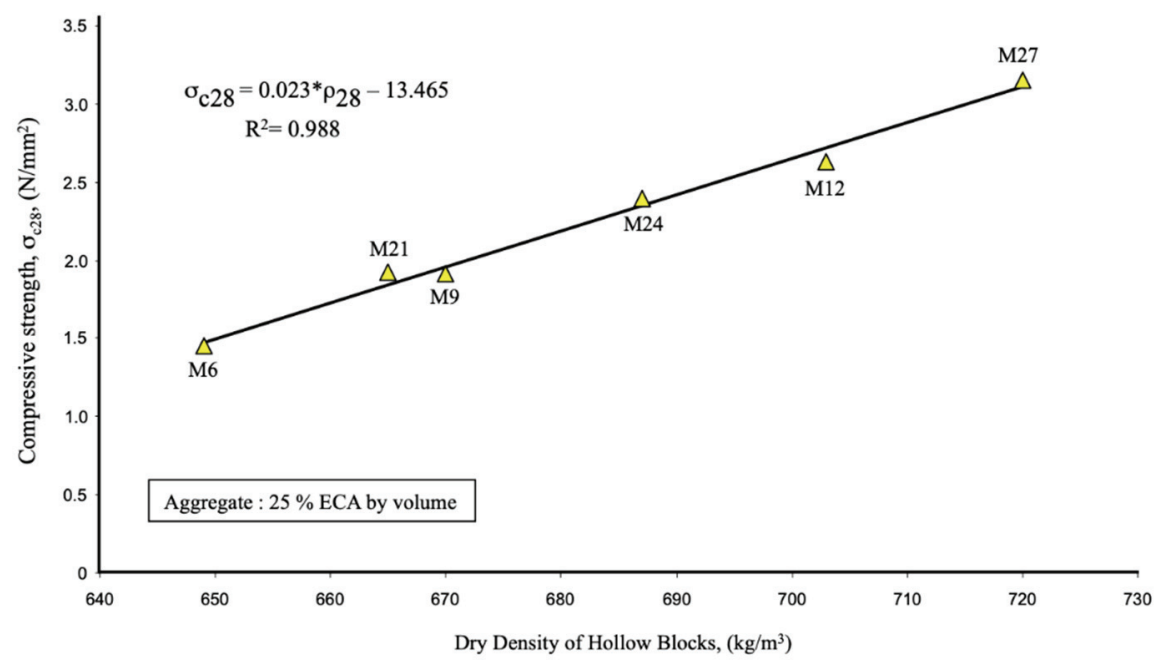

Figure 9 - The 28-day mean compressive strength of hollow blocks versus dry density of cubic specimens

An increase in C/A or cement content does not result in an increase in the bulk volume of concrete, additional cement is accommodated in the voids between the aggregate particles and their porous surfaces. The mixing water demand increases with increasing fine lightweight aggregate content. The results show that, unlike $\mathrm{W} / \mathrm{C}$ ratio, an increase in $\mathrm{A} / \mathrm{C}$ ratio seems to result in an increase in compressive strength of LCHC blocks, too. An examination of the data in Table 7 shows also that the minimum required strength according to BS 6073 is not achieved in LCHC blocks without VTP. 


\subsection{Water Penetration and Absorption}

Lightweight hollow concrete masonry unit specifications typically establish upper limits on the amount of water permitted to be absorbed. Expressed in kilogram of water per cubic meter of concrete, these limits vary with the density classification of the unit. Although no limit value for water absorption has been stated in BS 6073: Part 1 for the concrete masonry units, US National Concrete Masonry Association proposes that the maximum water absorption should be lower than $288 \mathrm{~kg} / \mathrm{m}^{3}$ for lightweight concrete masonry units [32]. The mean values for water absorption of LCHC blocks are given in Table 7. In this table, it is clearly observed that all absorption values are in the range of $100 \mathrm{~kg} / \mathrm{m}^{3}$ and $170 \mathrm{~kg} / \mathrm{m}^{3}$, within the acceptable water absorption values according to US National Concrete Masonry Association recommendation. The research findings show that there is a close relation between water absorption and compressive strength of lightweight masonry blocks, as illustrated in Figures 10 and 11 for different mixes. The analysis results show that there is a logarithmic relationship between the compressive strength and water absorption for LCHC blocks. The increases in the compressive strengths of masonry units are generally associated with reduction in water absorptions and an increase in cement and VTP contents. The increases in cement and VTP contents are the major factors reducing the water absorption of the masonry units. Unlike the cement and VTP contents, the increase of diatomite aggregate content is an effective factor increasing the water absorption capacity of LCHC blocks due to diatomite aggregates having high porosities. The water absorption values of LCHC blocks without VTP approximately range between $140 \mathrm{~kg} / \mathrm{m}^{3}$ and $170 \mathrm{~kg} / \mathrm{m}^{3}$. This range is higher than that of the mixes containing VTP and ECA. While the absorption values are not directly related to masonry unit physical and geometrical properties such as dimension, pore size and to mechanisms of deterioration such as freeze-thaw, they do provide a measure of the void structure within the lightweight concrete of the masonry unit. Several production variables can affect the void structure, including degree of compaction, binder and water content of the plastic mix, aggregate gradation and the parameters of the mixing operation.

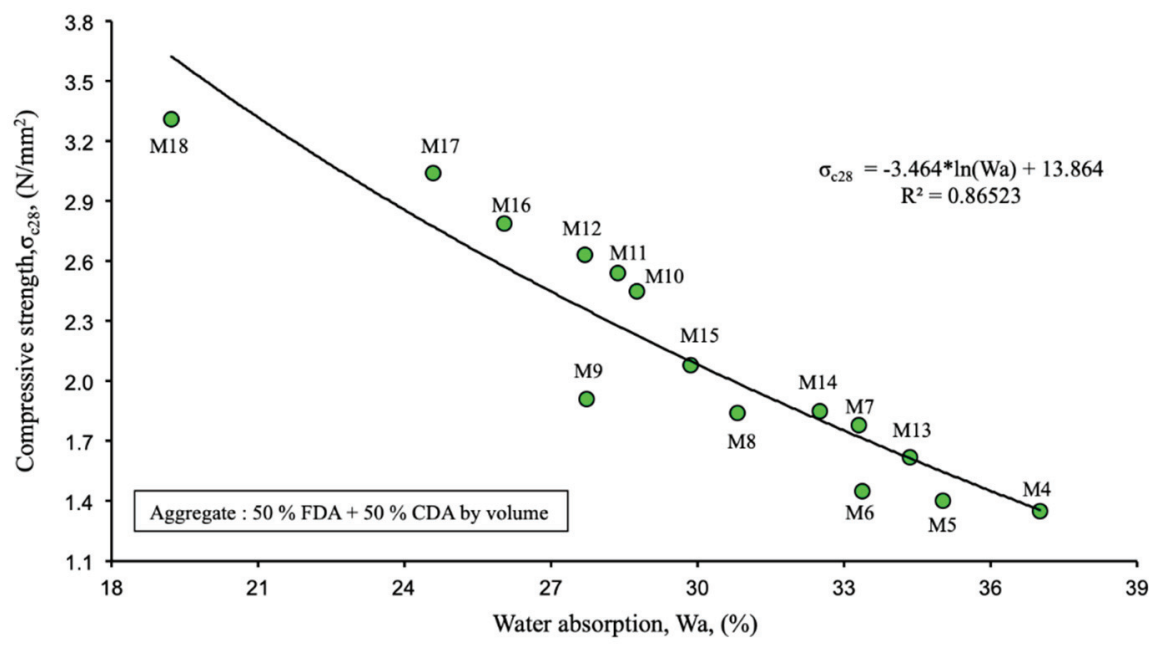

Figure 10 - The 28-day mean compressive strength versus water absorption of hollow blocks 
Due to the vesicular structure of lower density units, there is a potential for higher measured absorption than is typical for higher density units [32]. This effect is observed in LCHC blocks almost for all mixes.

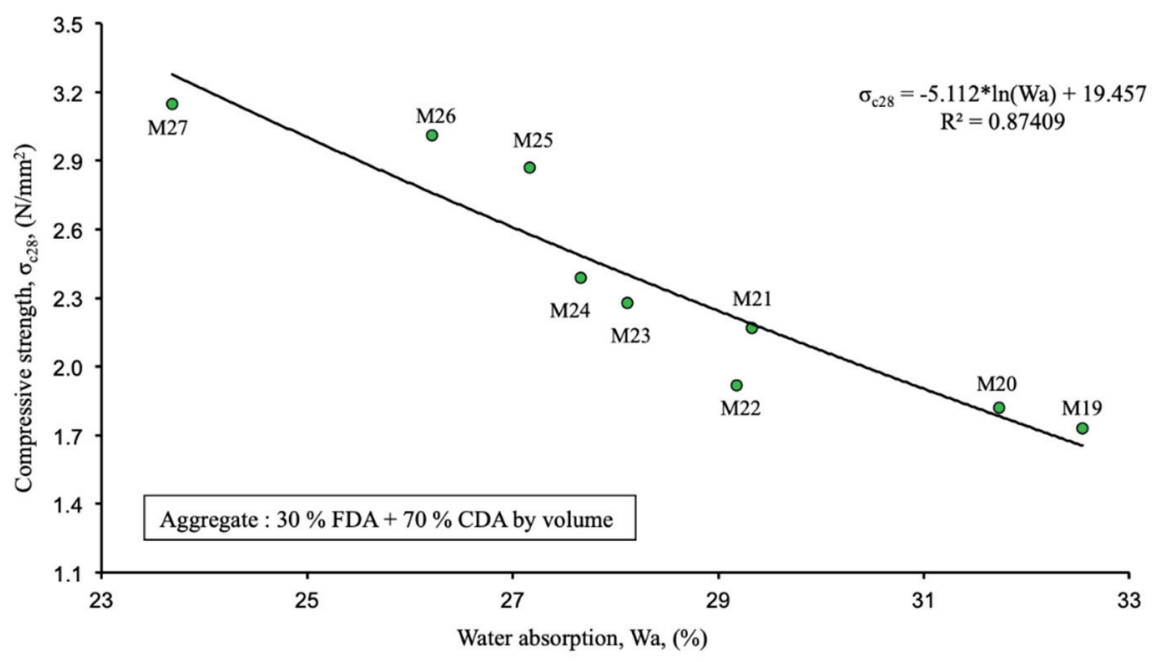

Figure 11 - The 28-day mean compressive strength versus water absorption of hollow blocks

Consequently, ASTM C 90 permits lower density lightweight masonry units to have higher maximum absorption values. The higher absorption limits permitted by ASTM C 90 for lower density units do not necessarily correlate to reduced water penetration resistance. One reason is that water penetration resistance is known to be highly affected by workmanship and dependent on detailing for water management. It is generally recognized that these two factors more heavily influence the wall's water penetration resistance than do other factors, such as unit density [32]. Corroborating this view, it was generally observed in this research that increase of masonry density reduced the water penetration of LCHC blocks. For thermal comfort as affected by the building envelope, water content of masonry blocks should be kept as low as possible [2]. Although no limiting value for water absorption of concrete masonry units was stipulated in BS 6073 , it is usually accepted that less than $300 \mathrm{~kg} / \mathrm{m}^{3}$ of water absorption for individual masonry unit is more appropriate for the partitioning and curtain walls in buildings. When the test results evaluated according to water absorption limits of U.S. National Concrete Masonry Association $\left(<288 \mathrm{~kg} / \mathrm{m}^{3}\right)$, the experimental research study showed that LCHC blocks having less than $880 \mathrm{~kg} / \mathrm{m}^{3}$ of dry unit density provide the convenient water absorption capacity for quaternary blends containing volcanic tuff powder, expanded clay aggregate, diatomite and cement to produce LCHC blocks for non-load bearing walls and partitions (Table 7). 


\subsection{Masses of masonry units}

The research showed that increasing the cement and VTP content increases the block unit mass. On the other hand, an increase of diatomite aggregate content generally results in mass reduction of masonry units due to its comparatively very low particle density than cement, VTP and ECA. Masses of the hollow blocks containing only VTP and ECA aggregates varied between $11.86 \mathrm{~kg}$ and $11.98 \mathrm{~kg}$ and those containing ECA and diatomite aggregates without VTP varied between $6.20 \mathrm{~kg}$ and $7.48 \mathrm{~kg}$. In a combination of VTP, ECA, FDA and CDA, the masses of LCHC hollow blocks varied between $6.33 \mathrm{~kg}$ and $7.66 \mathrm{~kg}$. It was also observed that increase of coarse diatomite aggregate in the mixture reduced the mass of the blocks. In general, the experience for this reduction for the hollow blocks used in this research was approximately $3 \%$ block mass reduction versus $1 \%$ increase in coarse diatomite aggregate content. Assuming the mass of normal weight aggregate concrete masonry for non-load bearing walls and partitions vary between $14 \mathrm{~kg}$ and $27 \mathrm{~kg}$ depending on their unit design geometry, the research work showed that LCHC blocks are $55 \%$ to $72 \%$ lighter than normal weight concrete masonry units. Furthermore, under masonry production conditions in Turkey, it is seen that LCHC blocks are also found to be $27 \%-33 \%$ lighter than pumice aggregate lightweight concrete masonry units.

\section{CONCLUSIONS}

The properties of lightweight hollow concrete masonry units made of CEM I (Portland cement) volcanic tuff powder, expanded clay aggregate and diatomite aggregates were investigated in this research work. The LCHC blocks were manufactured using mix compositions in current use and applying common production technology complying with the requirements of BS 6073: Part 1 and Part 2 [26]. It was possible to manufacture standard shape and size LCHC blocks using dry to stiff consistency mixtures to keep their shape and size during the demoulding, curing and hardening processes. The dry densities of the LCHC blocks complied with the standard acceptable limits for lightweight hollow concrete masonry units (i.e., less than $880 \mathrm{~kg} / \mathrm{m}^{3}$ ).

The research findings show that the higher the amount of diatomite aggregates in the mixture, the lesser the dry density of LCHC blocks. Addition of VTP in a mixture increases the block strength. An increase of $2 \%$ (by apparent volume) VTP with ECA provides approximately $18.5 \%$ to- $19.0 \%$ increase in the compressive strengths of the blocks. Lightweight concrete mixtures of $7 \%$ and $9 \%$ CEM I contents containing appropriate amounts of $50 \%$ FDA +50 $\%$ CDA or $30 \%$ FDA $+70 \%$ CDA mixtures by apparent volume do not qualify for use in producing CHLM blocks due to their insufficient strengths. All the mixtures with $9 \% \mathrm{CEM}$ I by apparent volume with only VTP and ECA aggregate mixes do comply with the strength requirements of BS 6073 .

The volcanic tuff powder particles' being covered with cement paste tends to reduce the water absorption of the particles, and also to improve the adherence between the hardened cement paste and the surface of aggregate particles. It was noticed that there is a significant difference between the compressive strengths of LCHC blocks produced with only VTP+ECA and those with VTP+ECA+FDA+CDA. In fact, the compressive strengths of LCHC blocks with only $\mathrm{VTP}+\mathrm{ECA}$ are $20 \%$ to $70 \%$, and, on the average almost $50 \%$ higher than the respective strengths of $\mathrm{LCHC}$ with $\mathrm{VTP}+\mathrm{ECA}+\mathrm{FDA}+\mathrm{CDA}$. Therefore, it is necessary to conduct 
additional research work in order to improve the material properties of the LCHC with $\mathrm{VTP}+\mathrm{ECA}+\mathrm{FDA}+\mathrm{CDA}$. The evaluation of the diatomite- Portland cement compatibility in masonry concrete mixtures is a technical aspect that should be further studied.

Within the $2.8 / 1$ to $7.3 / 1$ range of $A / C$ ratios, oven dry densities between $452 \mathrm{~kg} / \mathrm{m}^{3}$ and 874 $\mathrm{kg} / \mathrm{m}^{3}$ and compressive strength values between $1.35 \mathrm{~N} / \mathrm{mm}^{2}$ and $4.16 \mathrm{~N} / \mathrm{mm}^{2}$ can be achieved depending on the mixture proportions. Water absorptions of LCHC blocks, in the present investigation varied between $107 \mathrm{~kg} / \mathrm{m}^{3}$ and $168 \mathrm{~kg} / \mathrm{m}^{3}$. Although no limiting value for water absorption has been stated in BS 6073: Part 1 for the concrete masonry units, U.S. National Concrete Masonry Association proposes that the maximum water absorption should be lower than $288 \mathrm{~kg} / \mathrm{m}^{3}$ for lightweight concrete masonry units. Very low water absorption values were determined in this research as compared to the water absorption limit of U.S. National Concrete Masonry Association. The masses of LCHC blocks produced are found to be $55 \%$ - to $72 \%$ less than those of the normal weight hollow units. This could be considered as an important parameter in terms of reducing dead loads in buildings.

According to the results of the research, the compressive strength value of M3 mixture, which does not contain diatomite, was determined as the highest compressive strength value (4.6 $\mathrm{MPa}$ ). However, as a function of the high compressive strength value, the unit volume value of the block is also quite high $\left(874 \mathrm{~kg} / \mathrm{m}^{3}\right)$. The low unit weight and high strength masonry block product with the quaternary mixture content according to the concept of the study was obtained in M18 coded mixture design. The average compressive strength of these blocks is $3.31 \mathrm{MPa}$, the unit weight is $557 \mathrm{~kg} / \mathrm{m}^{3}$ and the water absorption is $107.07 \mathrm{~kg} / \mathrm{m}^{3}$. The lowest water absorption value is achieved by this mixture design. On the other hand, if it is desirable to produce $\mathrm{LCHC}$ with a lower unit weight, it is necessary to make some concessions from compressive strength and water absorption values. The M25 mixture, which has a lower volume weight, seems to be positive in this regard. It provides the required standard values for compressive strength and at the same time it has a relatively low unit weight.

It is advised that the thermal insulation, sound absorption and drying shrinkage properties of these LCHC blocks could be studied as a future work. Hence, the effects of VTP, FDA and CDA can be examined in more detail.

\section{References}

[1] CEM IA, Concrete Masonry Units, America's Cement Manufacturers, 2016, USA

[2] Gündüz L., Use of quartet blends containing fly ash, scoria, perlitic pumice and cement to produce cellular hollow lightweight masonry blocks for non-load bearing walls. Construction and Building Materials 22, 747-754, 2008.

[3] Turkmenoglu, A. G., Tankut, A., Use of tuffs from central Turkey as admixture in pozzolanic cements assessment of their petrographical properties. Cem. Concr. Res. 32, 4, 629-637, 2002.

[4] Faella, G., Manfredi, G., Realfonzo, R., Cyclic behaviour of tuff masonry walls under horizontal loading. Proc. 6th Can. Masonry Symp., Canada, 317-328, 1992. 
[5] Iwaro, J., Mwasha, A., Effects of using coconut fiber-insulated masonry walls to achieve energy efficiency and thermal comfort in residential dwellings. Journal of Architectural Engineering, 25(1), 04018035, 2019.

[6] Mahoutian, M., Chaallal, O., Shao, Y., Pilot production of steel slag masonry blocks. Canadian Journal of Civil Engineering, 45(7), 537-546, 2018.

[7] Annual books of ASTM standards, volume 04.02 and Volume 04.03, 2002.

[8] Gündüz, L., A technical report on lightweight aggregate masonry block manufacturing in Turkey. Suleyman Demirel University, Isparta, Turkey, 1-110, 2005.

[9] Weber, S., Curing of high strength concrete using lightweight aggregates, Bauberatung Zement Stuttgarti Loenberg. 377-391, 1997.

[10] BS 812: Part 2, Testing aggregates. Methods for determination of density, 1995, UK.

[11] BS 812 : Part 110, Testing aggregates. Methods for determination of aggregate crushing value (ACV), 1990, UK.

[12] ASTM C127-04 Standard test method for density, relative density (specific gravity), and absorption of coarse aggregate, USA.

[13] ASTM C128-04a Standard test method for density, relative density (specific gravity), and absorption of fine aggregate, USA.

[14] Ritmann, L., Volcanoes. London, UK: Orbis Publishing; 1980.

[15] Toprak, M.U. and Arslanbaba, M. A., Possibility of using Kütahya Volcanic Tuff as building stone: Microstructural evaluation and strength enhancement through heat treatment. Construction and Building Materials, 110, 128-134, 2016.

[16] Wang J., Jung W., Li Y. And Ghassemi A., Geomechanical characterization of Newberry Tuff. Geothermics, 63, 74-96, 2016.

[17] Tuncay, E., Rock. Original Research Article, International Journal of Rock Mechanics and Mining Sciences, 46(8), 1253-1266, 2009.

[18] Özguven, A. Genleşen kil agrega üretimi ve endüstriyel olarak değerlendirilmesi. PhD thesis. Isparta: University Süleyman Demirel; 2009 [in Turkish].

[19] Özguven, A. and Gunduz, L., Examination of effective parameters for the production of expanded clay aggregate. Cement \& Concrete Composites 34, 781-787, 2012.

[20] Doğan, H. and Şener, F., Hafif yapı malzemeleri (pomza-perlit-ytong-gazbeton) kullanımının yaygınlaştırılmasına yönelik sonuç ve öneriler. TMMOB. The Newsletter of the Chamber of Geology Engineers, 1, 51-53, 2004 [in Turkish].

[21] Ha, J.H., Lee, J., Song, I. H. and Lee, S. H., The effects of diatomite addition on the pore characteristics of a pyrophyllite support layer. Ceramics International, 41(8), 9542-9548, 2015.

[22] Xu, S., Wang, J., Jiang, Q. and Zhang, S., Study of natural hydraulic lime-based mortars prepared with masonry waste powder as aggregate and diatomite/fly ash as mineral admixtures. Journal of Cleaner Production, 119, 118-127, 2016. 
[23] Inchaurrondo, N., Font, J., Ramos, C.P., Haure, P., Natural diatomite: Efficient green catalyst for Fenton-like oxidation of Orange II. Applied Catalysis B: Environmental, 181, 481-494, 2016.

[24] BS 1881: Part 125, Testing concrete. Methods for mixing and sampling fresh concrete in the laboratory, 1986, UK.

[25] BS 1881: Part 114, Testing concrete. Methods for determination of density of hardened concrete, 1983, UK.

[26] BS 6073: Part 1, Precast concrete masonry units. Specification for precast concrete masonry units, 1981, UK.

[27] Abali, Y., Bayca, S. U., Targan, S., Evaluation of blends tincal waste, volcanic tuff, bentonite and fly ash for use as a cement admixture. J. Hazard. Mater., 131, 126-130, 2006.

[28] Smadi, M. M., Migdady, E., properties of high strength tuff lightweight aggregate concrete. Cem. Concr. Comp., 13(2), 129-135, 1991.

[29] Faustino, J., Silva, E., Pinto, J., Soares, E., Cunha, V.M.C.F., and Soares, S., Lightweight concrete masonry units based on processed granulate of corn cob as aggregate. Materiales de Construcción, 65(318), e055, 2015.

[30] BS EN 771-3, 2011, Specification for masonry units. Aggregate concrete masonry units (dense and lightweight aggregates).

[31] Neville, A.M., Properties of concrete. London, Longman Scientific and Technical series, 2000.

[32] TEK 2-6, Density-related properties of concrete masonry assemblies, National Concrete Masonry Association, an information series from the national authority on concrete masonry technology, 2008, USA.

[33] Holm, T. A., Engineered masonry with high strength lightweight concrete masonry units. Concrete Facts, 17(2), 1972. 
